\title{
PRODUK SENI NUSANTARA DALAM KONTEKS EKONOMI KREATIF
}

\author{
Muh. Abdul Aziz \\ Program Pascasarjana, Universitas Diponegoro \\ E-mail: muhammadaziz085@gmail.com
}

\begin{abstract}
Abstrak
Ekonomi kreatif menjadi salah satu tulang punggung pertumbuhan perekonomian Negara. Kita dapat mengamati bahwa industri kreatif semakin aktif sehingga penyerapan tenaga kerja akan semakin tinggi dan dapat di pastikan pengangguran akan semakin berkurang. Terbukti pada tahun 2014 ekonomi kreatif berkontribusi sebesar 7,1\% terhadap PDB nasional, mampu menyerap 12 juta tenaga kerja, serta memberikan kontribusi perolehan devisa negara sebesar $5,8 \%$. Namun beberapa sub-sektor yang ada di dalam ekonomi kreatif, potensi di bidang seni (kriya, seni rupa, tari, dan musik) masih dirasa kurang maksimal. Artikel ini merupakan sebuah upaya menganalisis potensi seni di bidang ekonomi kreatif dalam memaksimalkan penjualan produk/jasa kesenian. Peneliti mencoba mengkaji potensi seni dengan menggunakan teori dari Philip Kotler, yaitu teori bauran pemasaran (marketing mix). Alat-alat bauran pemasaran (marketing mix) yang populer sering digunakan meliputi: produk (product), harga (price), saluran distribusi (place), dan promosi (promotion). Studi ini menggunakan pendekatan deskriptif-kualitatif dengan metode studi literatur.
\end{abstract}

Kata kunci: produk seni, ekonomi kreatif, bauran pemasaran.

\section{NUSANTARA ART PRODUCTS IN THE CONTEXT OF CREATIVE ECONOMY}

\begin{abstract}
Creative economy has become one of the backbones of the country's economy growth. We can observe that the creative industries are increasingly active so the absorption of labor will be higher and can make sure that unemployment will be reduced. Proven in 2014 the creative economy account for $7.1 \%$ to GDP, able to absorb 12 million workforce, as well as foreign exchange earnings contributing countries amounted to $5.8 \%$. However, some sub-sectors in the creative economy, the potential in the field of Arts (fine art, craft, dance, and music) are still considered insufficient. This article will analyze the potential of art in economics creative in maximizing the sales of your products/services. Researchers try to assess the potential of art by using the theory of Philip Kotler, i.e. the theory of marketing mix. The tools of marketing mix (the marketing mix) which is popular often used include: product (product), the price (price), the distribution channels (place), and promotion (promotion). This study used a descriptive-qualitative approach using methods of study of literature.
\end{abstract}

Keywords: art product, creative economic, the marketing mix.

\section{PENDAHULUAN}

Seni merupakan kegiatan manusia untuk berusaha menciptakan bentuk-bentuk yang menyenangkan. Bentuk yang menyenangkan berarti bentuk yang dapat membingkai perasaan keindahan, dan perasaan keindahan itu dapat terpuaskan apabila dapat menangkap harmoni atau satu kesatuan dari bentuk yang disajikan 
(Read, 1959:1). Dikemukakan pula oleh De Witt H. Parker yang menganggap seni sebagai ekspresi suatu ungkapan. Ungkapan dapat dilukiskan sebagai pernyataan suatu maksud perasaan atau pikiran dengan suatu medium indra atau lensa yang dapat dialami lagi oleh yang mengungkapkan dan ditujukan atau dikomunikasikan kepada orang lain (Parker, 1946:13).

Secara umum, kesenian dapat mempererat ikatan solidaritas suatu masyarakat. Interaksi antara manusia dengan alam sekitar banyak hubungannya dengan penciptaan karya seni baik dari sisi motivasi penciptaan maupun hasilnya kemudian (Sp, Soedarsono, 2006:14). Memahami kesenian itu berarti menemukan sesuatu gagasan atau pembatasan yang berlaku untuk menentukan hubungan dengan unsur nilai dalam budaya manusia (Humardani, 1980:2). Kesenian dapat dikatakan sebagai salah satu bagian dari kebudayaan dan sebagai sarana yang digunakan dalam menuangkan ekspresi rasa keindahan dalam jiwa manusia. Selain itu kesenian juga berfungsi sebagai mitos yang mempertahankan norma dan nilai dalam kehidupan bermasyarakat. Dapat kita temukan hal-hal yang berkaitan erat dengan kesenian diantaranya adalah sebagai ritual, simbol, komunikasi, religi, ekspresi, hingga pendidikan, selain hal itu kesenian juga memiliki peran penting dalam bidang ekonomi. Produkproduk karya seni baik dari seni rupa maupun seni pertunjukan menjadi salah satu penopang perekonomian Indonesia.

Indonesia dalam persaingan ekonomi dunia perlu memperkuat daya saing antar negara. Maka perlu adanya sinergisitas antara pemerintah dengan para pelaku bisnis/usaha agar dapat mengubah persaingan antar negara menjadi peluang (treath) positif untuk perekonomian di Indonesia. Bayak pekerjaan rumah yang harus dikerjakan oleh pemerintah Indonesia yang paling pokok adalah berita-berita yang sering kita lihat dan dengar di media televisi maupun media cetak yang lain yaitu masalah birokrasi, banyaknya pungli menjadi kegelisahan bagi para pelaku usaha, perizinan yang rumit dan logistik yang dapat menambah biaya produksi.
Diharapkan pemerintah dapat mempermudah dan mempercepat proses-proses perizinan dan membangun infrastruktur-infrastruktur logistik yang memadai sehingga akan mendorong para pelaku usaha dalam menciptakan produk dan jasa.

Konsep ekonomi dibagi menjadi dua, yaitu ekonomi positif dan ekonomi normatif. Ekonomi positif yaitu pendekatan ekonomi yang mempelajari berbagai pelaku dan proses bekerjanya aktifitas ekonomi, tanpa menggunakan suatu pandangan subyek untuk mengatakan bahwa sesuatu itu baik atau jelek dari sudut pandang ekonomi. Ekonomi positif dibagi menjadi dua yaitu ekonomi deskriftif dan ekonomi teori. Sedangkan ekonomi normatif adalah pendekatan ekonomi dalam mempelajari prilaku ekonomi yang terjadi, dengan mencoba memberikan penilaian baik atau buruk berdasarkan pertimbangan subyek (Hasoloan, 2010:9).

Beberapa tahun terahir sejak terbentuknya MEA (Masyarakat Ekonomi Asean) yang bertujuan melakukan perdagangan bebas lintas Asia tanpa dikenakan bea cukai yang tinggi, bahkan bebas bea cukai. Indonesia mencoba ikut andil dalam pola pengintegrasian ekonomi diwilayah benua Asia tersebut. Ada diantaranya negara-negara yang ikut dalam perdagangan bebas lintas Asia seperti: Malaysia, Filipina, Singapura, Laos, Brunai Darussalam, Kamboja, Vietnam, Laos, Myanmar, dan Indonesia. Hal itu tentu membuat Pemerintah Indonesia memutar otak untuk merancang strategi baru agar mendapatkan keuntungan maksimal dari keikutsertaan dalam MEA atau bisa disebut AEC (ASEANEconomic Community). Menggencarkan dan mengkampanyekan ekonomi kreatif menjadi bagian pembicaraan yang serius dalam dunia ekonomi, politik, dan juga budaya, karena diyakini akan menjadi salah satu tulang punggung dalam pertumbuhan ekonomi. Bila dikaitkan dengan industri pariwisata yang ada Indonesia, dimana pertunjukan kesenian, pentas musik tradisional, pameran kriya seni, wisata bersejarah, dan lokasi yang diciptakan dengan harapan untuk mendukung berkembanya ekonomi kreatif masyarakat Indonesia. 
Perubahan iklim yang terjadi di seluruh dunia menjadi sorotan utama terkhusus bagi warga Indonesia, perubahan dari zaman agraria menuju zaman industrial, disusul dengan zaman informasi yang dibarengi dengan perkembangan pesat di bidang teknologi informasi serta globalisasi ekonomi telah membawa kehidupan baru bagi masyarakat seluruh dunia terkhusus masyarakat Indonesia sendiri.

Sekitar pada tahun 2012 kita dapat merasakan bahwa kompetitif dari masing-masing industri kreatif di Indonesia semakin ketat dan berkembang sangat pesat. Belakangan ini masyarakat kita banyak yang memprediksikan akan pertumbuhan di bidang industri kreatif akan naik cukup tinggi dikarenakan kebutuhan untuk berkreasi dan dorongan dari pemerintah Indonesia sangat baik. Beberapa contoh belakangan ini kita dapat mengamati bahwa industri kreatif semakin aktif sehingga dapat dipastikan penyerapan tenaga kerja akan semakin tinggi dan jumlah pengangguran semakin berkurang. Terbukti pada tahun 2014 ekonomi kreatif berkontribusi sebesar 7,1\% terhadap PDB nasional, mampu menyerap 12 juta tenaga kerja, serta memberikan kontribusi perolehan devisa negara sebesar $5,8 \%$. Hal ini sangat berdampak positif untuk pertumbuhan perekonomi di Indonesia. Mengamati perkembangan positif ekonomi kreatif maka perkembangan dan pertumbuhan ekonomi kreatif di Indonesia secara kolektif perlu diintegrasikan ke dalam sistem perekonomian Indonesia secara utuh, sehingga Indonesia memiliki ketahanan ekonomi sekaligus ketahanan budaya (Romarina, 2016:39).

Persoalan mendasar berhubungan dengan ekonomi yang harus dijawab oleh setiap bangsa adalah bagaimana kehidupan ekonomi nasional, yang melibatkan berjuta-juta manusia dan ratusan ribuan bahkan jutaan perusahaan kecil maupun besar, harus diatur dan diorganisir agar berjalan dengan baik. Tata ekonomi sendiri menunjukan bagaimana suatu masyarakat mengorganisir kehidupan ekonominya untuk menjawab pokok masalah ekonomi: apa dan berapa yang dihasilkan, bagaimana, dan untuk siapa (Gilarso, 2004). Tata kelola ekonomi di Indonesia sudah jelas diatur dalam UUD 1945 khususnya pasal
33, dirinci dalam Garis-Garis Besar Haluan Negara dan disebut dengan demokrasi ekonomi: produksi diusahakan sebagai usaha bersama untuk kepentingan bersama. Tata kelola ekonomi Indonesia memberikan kebebesan usaha untuk setiap warganya/penduduknya, dalam batasbatas dan syarat-syarat tertentu. Dalam usaha produksi masyarakat sendiri sebagaian besar usaha swasta. Ada pula perusahaan milik negara baik di bidang pertanian atau perkebunan, pertambangan, industri, dan transportasi. Jadi diusahakan adanya keseimbangan yang wajar atara unsur kebebasan dan unsur pengendalian. Maka sistem ekonomi disebut sebagai sistem ekonomi bebas kendali.

Undang-undang Dasar 1945, Pasal 33 setelah amandemen 2002: (1) Perekonomian disusun sebagai usaha bersama berdasarkan asas keluarga; (2) Cabang-cabang produksi yang penting bagi negara dan yang menguasai hajat hidup orang banyak dikuasai oleh negara; (3) Bumi dan air dan kekayaan alam yang terkandung didalamnya dikuasai oleh negara dan dipergunakan untuk sebesar-besarnya kemakmuran rakyat; dan (4) Perekonomian nasional diselenggarakan berdasarkan atas demokrasi ekonomi dengan prinsip kebersamaan, efisiensi berkeadilan, berkelanjutan, berwawasan lingkungan, kemandirian serta dengan menjaga keseimbangan kemajuan dan kesatuan ekonomi nasional (Gilarso, 2004:375).

Peraturan Presiden Nomor 72 Tahun 2015 tentang Perubahan Atas Peraturan Presiden Nomor 6 Tahun 2015 Tentang Badan Ekonomi Kreatif dalam pasal dua telah mengklasifikasi ulang sub-sektor industri kreatif dari 15 subsektor menjadi 16 sub-sektor, yaitu (1) arsitektur, (2) desain interior, (3) desain komunikasi visual, (4) desain produk, (5) film, animasi, video, (6) fotografi (7) kriya, (8) kuliner, (9) musik, (10) fashion, (11) aplikasi dan game developer, (12) penerbitan, (13) periklanan, (14) televisi dan radio, (15) seni pertunjukan, dan (16) seni rupa. Dalam perpres nomor 72 tahun 2015 ini dijelaskan bahwa yang tergolong dalam ekonomi kreatif meliputi enam belas sub sektor (Perpres, 2015). 
Dalam artikel akan diulas tentang potensipotensi produk dan jasa seni dalam usaha dan pengelolaanya. Selanjutnya, akan digali juga potensi yang ada dalam produk seni dan jasa sebagai pendorong produktifitas dalam konteks ekonomi kreatif, dengan memfokuskan ke dalam sub sektor industri kreatif dibidang kesenian yang meliputi empat hal yaitu: (1) Kriya/ kerajinan, (2) Seni Rupa/pasar barang seni, (3) Tari/pertunjukan), (4) Musik Tradisional/ musik.

\section{KESENIAN DAN PRODUK SENI}

Kesenian adalah ekspresi dari kejujuran jiwa, cerminan jiwa, ungkapan jiwa yang divisualkan melalui berbagai macam media (Sunarya, 2005:84). Pendapat lain mengatak kesenian merupakan pembangunan dari dalam jiwa manusia. Dalam bentuk-bentuk kesenian, tertuang sikap hidup yang akan memberikan arah pada pembangunan phisik. Kesenian adalah tempat untuk mengembangkan gagasan sebelum ia beroleh berwujud fhisik. Kesenian juga merupakan bagian yang penting dalam pembangunan phisik juga. Berbagai bentuk kesenian telah lama hidup subur didalam masyarakat. Kesenian sudah menyelusup pada kehidupan sehari-hari. Tapi malangnya, ketika arus pembangunan phisik digalakan, sektor tegnologi, ekonomi politik menjadi primadona, kesenian mulai tersisih, tidak diperhitungkan sama sekali, bahkan nyaris tercampakan sebagai pemborosan energi dan doku. Kesenian pun mulai dimusuhi. Kesenian sebagai alat untuk mencurahkan makna, agar bisa ditumpahkan kepada seseorang secara tuntas (Wijaya, 2001:15).

Kesenian merupakan bagian yang sangat penting dari nilai kebudayaan. Kesenian bukanlah barang mewah yang dapat dinikmati oleh kelompok-kelompok tertentu saja., namun menjadi milik setiap orang yang mampu mengenali emosi estetis yang muncul didalam dirinya. Dalam sejarah perkembangan kesenian telah menjadi faktor penting bagi terciptanya integrasi, kreativitas kultur, sosial atau pun individu (Sutardi, 2007:15).
Produk seni kriya seiring dengan perkembangan zaman, seni kriya mencoba untuk berkembang mengikuti kebutuhan manusia. Seni kriya hadir pada semua jenjang kehidupan masyarakat, baik kalangan ekonomi lemah, menengan maupun ekonomi atas. Sebagai contoh karya-karya yang dihasilkan oleh pekriya meliputi: topeng dari malang, topeng cirebon dan ada pula karya kriya yang tidak terfokus akan karya kedaerahan melainkan bersifat nasionalis, misal berbagai produk mebel, barang-barang kulit, tembaga, keramik/gerabah, dan produk yang lain. disisi lain banyak juga hasil produk kriya yang memfokuskan pada khas kedaerahan si pembuat contoh saja wayang kulit gaya yogyakarta, surakarta dan masih banyak yang lain (Kusmadi, 2010:65).

Produk seni rupa sering kita jumpai dalam aktivitas kehidupan sehari-hari seperti halnya seni rupa terapan. Dalam kehidupan seharihari seni rupa terapan tidak hanya bernilai sebagai seni tetapi mempunyai kegunaan dalam kehidupan. Seperti Contoh karya seni rupa terapan meliputi pakaian, rumah adat dan masih banyak yang lain. Di Indonesia karya seni rupa terapan mancanegara berupa kerajinankerajinan yang sangat banyak sekali jenisnya, antara lain: keramik, anyaman, batik dan tenun. setiap negara mempunyai unggulan dalam hal menghasilkan seni rupa terapan, contohnya Cina terkenal dengan keramiknya, negara timur tengan terkenal dengan produk karpetnya dan india terkenal dengan produk perhiasanya. setiap produk yang di hasilkan karya seni memiliki keunikan dan kekhasan tersendiri sehingga produk tersebut dapat dijadikan cap dari mana produk berasal (Margono, 2007:76). Dari penjelasan seni rupa merupakan produk yang dihasilkan untuk memenuhi hajat masyarakat guna dapat di gunakan sebagaimana fungsinya. Ada pula karya-karya seni rupa murni seperti halnya kerajinan kayu, kerajinan bambu, kerajinan patung, kerajinan rotan, kerajinan kaca dan lain-lain.

Produk seni tari tradisional memiliki peranan besar dalam aktivitas masyarakat dimana tarian tersebut tumbuh dan berkembang. Peranan dalam tarian itulah yang membuat 
masyarakat dikenali sebagai ciri khas daerah, dan sebagai media komunikasi budaya. Seperti halnya tari tradisional Rembara dari daerah Kabupaten Paser sebagai media menyampaikan pesan-pesan kepada masyarakat dan dapat mempengaruhi kehidupan agar lebih baik. Pesan yang terkandung dalam tari rebara mengandung makna mendidik masyarakat untuk berbudi pekerti yang baik terhadap orang lain (Tridayanti, 2014:401). Produk lain dari sebuah pulau di Indonesia yaitu provinsi Bali yang memiliki kebudayaan yang sangat dikenal oleh seluruh penjuru dunia, Salah satunya adalah seni tarinya. Tari Bali merupakan tarian yang di hasilkan dari masyarakat dan mempunyai arti pencerminan perwatakan dari masyarakat itu. Seperti contoh, Seni tari Bali-balian (secular dance) adalah segala tari yang mempunyai unsur dan dasar tari yang luhur yang tidak tergolong tari wali ataupun tari bebali serta mempunyai fungsi sebagai seni serius dan seni hiburan. Contohnya, tari Legong Keraton, tari Joged (Putra \& Soehartono, 2012:2).

Produk seni musik baik tradisional maupun moderen sangat banyak terbentang dari sabang sampai merauke. Setiap provinsi di Indonesia memiliki musik tradisional dengan ciri khas tersendiri, contoh saja seperti musik gamelan dan seni musik tradisional termasuk juga keroncong yang berasal dari keturunan portugis di daerah tugu, jakarta, yang dikenal oleh semua rakyat Indonesia bahkan hingga ke mancanegara. Masih banyak juga Musik tradisional lainya berdasarkan dengan daerah masing-masing. ada pula musik yang merakyat di indonesia seperti dangdut yang dipengaruhi oleh musik Arab, India, dan Melayu. Alat musik tradisional di Indonesia sangat beragam dari berbagai daerah yang ada di Indonesia. Sebagaian contoh alat musik tradisional yang ada di indonesia antara lain meliputi: Angklung, Gamelan, Gendang Bali, Bende, Calung, Tabuik, Jidor, Kecapi Suling, Rebana, Sasando dan sebagainya (UUD, 2010:87).

\section{KONSEP EKONOMI KREATIF}

Berkaitan dengan pengembangan dan perkembangan Ekraf di Indonesia, Pemerintah sudah sejak tahun 2009 merespon akan hal tersebut, denganmengeluarkan Inpres No. 6 Tahun 2009 tanggal 5 Agustus tentang Pengembangan Ekonomi Kreatif Mendukung kebijakan Pengembangan Ekonomi Kreatif tahun 20092015, yakni pengembangan kegiatan ekonomi berdasarkan pada kreativitas, keterampilan, dan bakat individu untuk menciptakan daya kreasi dan daya cipta individu yang bernilai ekonomis dan berpengaruh pada kesejahteraan masyarakat Indonesia (Inpres, 2009).

Tujuan dari ekonomi kreatif tidak hanya terkait dengan penciptaan nilai tambah secara ekonomi, tetapi juga penciptaan nilai tambah secara sosial, budaya dan lingkungan. Ekrafsendiri mengupayakan agar terjadinya pembangunan yang berkelanjutan melalui kreativitas, dimana konsep dari sistem pembangunan berkelanjutan yaitu menciptakan iklim perekonomian yang berdaya saing dan memiliki cadangan sumber daya yang terbarukan memiliki potensi besar untuk menjadi salah satu sektor penggerak yang penting dalam mewujudkan Indonesia yang mandiri, maju, adil, dan makmur (Romarina, 2016:35).

Ekonomi kreatif merupakan sebuah "talenta" baru yang merubah pandangan pola fikir dalam kehidupan masyarakat melalui ide/ gagasan kreatif, sehingga menghasilkan produkproduk bernilai tambah ekonomi yang mampu menjadikan kehidupan lebih sejahtera. Arti "talenta" sendiri memiliki banyak definisi atau pengertian (Saksono, 2012:93). talenta adalah sesuatu yang dimiliki oleh karyawan yang dibangun dan dibina melalui program pelatihan dan pengembangan oleh suatu organisasi untuk proses jangka panjang mampu meningkatkan kinerjanya sehingga dapat menjadi pendorong dibalik kontribusi mereka terhadap keberhasilan organisasi (Sukoco \& Fadillah, 2016:87). Penjelasan diatas menerangkan bahwa dari kreatifitas individu akan menciptakan nilai ekonomi, sosial dan lingkungan. Secara ekonomi masyarakat akan lebih sejahtera dalam kehidupan sehari-hari, secara niala sosial mampu menciptakan lapangan pekerjaan yang cukup sehingga kesejahteraan sosial meningkat, secara lingkungan akan menambah nilai kebersamaan dalam pelaksanaan ekonomi kreatif. 
Kepopuleran dari Istilah Ekraf (Ekonomi Kreatif) bermula dari tokoh bernama John Howkins, dia menulis buku dengan judul "Creative Economy, How People Make Money from Ideas". Menurut pendapat Howkins, Ekonomi Kreatif merupakan aktivitas kegiatan ekonomi yang mengintenskan input dan outputnya adalah Gagasan yang dihasilkan individu. Bayangkan saja dengan modal ide dan gagasan seseorang akan mendapatkan keungtungan yang banyak. Gagasan yang dimaksudkan yaitu gagasan yang orisinil. Seperti halnya bintang film, penyanyi, musisi dan lain sebagainya (Anggraini, 2008).

Kementerian Pariwisata dan Ekonomi Kreatif mengidentifikasi ada tujuh potensi Ekraf yang menjadi fokus utama dalam pengembangan ekonomi kreatif periode 2015-2019. Yaitu diantaranya sebagai berikut.

1. Ketersediaan sumber daya kreatif (orang kreatif) yang profesional dan kompetitif. Indonesia memiliki karakteristik demografis yang potensial untuk mengembangkan ekonomi kreatif.

2. Jumlah penduduk dengan angkatan kerja yang tinggi dapat diarahkan untuk memperkuat industri kreatif lokal.

3. Industri yang berdaya saing, tumbuh, dan beragam.

4. Ketersediaan pembiayaan yang sesuai dan kompetitif. Isu strategis pembiayaan meliputi ketersediaan lembaga, sumber, dan akses pembiayaan.

5. Perluasan pasar bagi karya kreatif dalam bentuk penetrasi dan diversifikasi pasar dalam dan luar negeri.

6. Ketersediaan infrastruktur teknologi yang sesuai dan kompetitif.

7. Kelembagaan dan iklim usaha yang mendukung pengembangan ekonomi kreatif meliputi regulasi, partisipasi aktif pemangku kepentingan, pengarusutamaan kreativitas, partisipasi dalam forum internasional,dan apresiasi terhadap orang, karya, wirausaha, dan usaha kreatif serta terhadap sumber daya alam dan budaya (Romarina, 2016:45).

\section{BAURAN PEMASARAN (MARKETING MIX) MENURUT PHILIP KOTLER}

Kotler,(2000) mengatakan bauran pemasaran adalah kegiatan pemasaran yang bertujuan untuk mencapai tujuan pemasaran dalam pasar. Marketing Mix merupakan variabel-variabel terkendali yang digunakan untuk membuat konsumen tertarik akan karya atau produk yang dihasilkan oleh perusahaan. Alat-alat bauran pemasaran (marketing mix) yang populer sering digunakan meliputi: produk (product), harga (price), saluran distribusi (place), dan promosi (promotion). Dalam pencapaian tujuan pemasaran keempat alat bauran pemasaran harus saling mendukung dengan harapan tercapainya kepuasan konsumen (Kotler, 2000:18). Keberhasilan dalam penciptaan produk harus diikuti dengan pemasaran yang baik sehingga segmen pasar yang ditargetkan dapat terpengaruh. Penjelasan alat-alat bauran pemasaran (marketing mix) sebagai berikut.

1. Product (produk) adalah sesuatu yang dapat ditawarkan ke pasar untuk dapat diperhatikan, diraba atau tidak bisa diraba dan dibeli atau dikonsumsi menjelaskan bahwa produk adalah segala sesuatu yang dapat ditawarkan ke pasar untuk diperhatikan, diperloleh, digunakan, atau dipasarkan. Produk bisa dikategorikan seperti barang-barang (fisik), pengalaman, orang dan gagasan. Dalam merencanakan produk atau jasa yang baik perlu adanya pedoman dalam penciptaannya, apakah akan mengubah produk yang ada dan/menambah produk baru. Ada pula keputusan-keputusan dapat diambil menyangkut pemberian merek, kualitas, kemasan, bentuk, ukuran dan warnanya.

2. Price (harga) adalah nilai dari barang dan jasa yang dapat dibeli degan sejumlah uang. Atas dasar nilai tersebut perusahaan atau seseorang akan rela melepaskan barang maupun jasa yang dimilikinya untuk konsumen. Tentu harga suatu barang atau jasa menjadi faktor penentu dalam permintaan pasar. Harga juga dapat mempengaruhi posisi persaingan dengan perusahaan lain. Keputusan dalam 
penentuan harga tidak boleh dilakuakan secara sembarangan. Harus menentukan harga dasar dari produknya, menentukan pada saat kapan memberi potongan harga, pembayaran ongkos kirim dan hal-hal lain yang bersangkutan dengan harga. Seperti contoh produk yang umum, penurunan harga dapat menaikkan penjualan, sedangkan pada produk yang sudah mempunyai citra yang bagus, kenaikan harga akan menaikkan penjualan karena produk dengan harga tinggi akan menunjukkan kualitas produk itu sendiri.

3. Promotion (promosi) adalah sebuah aktivitas dalam mengkomunikasikan keunggulan produk dan merayu pelanggan agar mau membeli produk yang dihasilkan. Adapun kegiatan-kegiatan yang dimaksud adalah periklanan, penjualan secara pribadi, promosi penjualan, publisitas, hubungan masyarakat.

4. Place (saluran distribusi) adalah aktivitas perusahaan yang melakukan distribusi secara merata sehingga membuat produk mudah didapatkan oleh konsumen. Memilih perantara yang akan dilibatkan dalam saluran distribusi, serta mengembangkan sistem distribusi secara fisik dapat menangani dan mengangkut produk melalui saluran tersebut. dengan maksud agar produk dapat disalurkan kepada konsumen tepat pada waktunya.

\section{PRODUK SENI DALAM PERSPEKTIF EKONOMI KREATIF}

Tabel 1 dapat dilihat bahwa pertumbuhan dari produk seni yang meliputi nomor (1), (2), (3), (4) memiliki potensial yang sangat bagus dari tahun ke tahun dan perlu ditingkatkan guna menunjang laju pertumbuhan ekonomi kreatif sehingga akan berdampak positif untuk ekonomi di Indonesia.

\section{Kriya (Kerajinan)}

Seni kriya merupakan bagian dari seni rupa pada umumnya, yang memiliki kedudukan krusial di dalam kehidupan masyarakat Indonesia dan termasuk tergolong seni yang paling tua. Pemahaman tersebut didasari oleh karya-karya peninggalan nenek moyang kita mulai dari gerabah, logam tembaga, lumbung, dan sebagainya yang dapat kita lihat di museummuseum yang ada (Kusmadi, 2010:64). Seni kriya adalah seni yang menyandang tugas untuk memenuhi kebutuhan manusia dalam kehidupan sehari-hari (Soedarso, 2006:104). Kedudukan

Tabel 1. Daftar Kontribusi Sub-Sektor Industri Kreatif Perekonomian Indonesia

\begin{tabular}{|c|c|c|c|c|c|}
\hline NO & $\begin{array}{l}\text { LAPANGAN USAHA } \\
\text { INDUSTRI KREATIF }\end{array}$ & 2010 & 2011 & 2012 & 2013 \\
\hline 1. & Pasar barang seni & 1372,1 & $1.559,50$ & 1737,4 & 2001,3 \\
\hline 2. & Kerajinan & $72.955,20$ & $79.516,70$ & $84.222,90$ & $92.650,90$ \\
\hline 3. & Musik & $3.972,70$ & $44.775,40$ & $4.798,90$ & $5.237,10$ \\
\hline 4. & Seni pertunjukan & $1.897,50$ & $2.091,30$ & $2.294,10$ & $2.595,30$ \\
\hline 5. & Periklanan & $2.534,70$ & 2896,6 & 3168,3 & 3754,2 \\
\hline 6. & Arsitektur & $9.243,90$ & $10.425,60$ & 11510,3 & $12,890,90$ \\
\hline 7. & Desain & $19.583,20$ & $21.018,60$ & $22.234,50$ & $25.042,70$ \\
\hline 8. & Fasion & $127.817,25$ & $147.503,20$ & $164.538,30$ & $181.570,30$ \\
\hline 9. & Film, video dan fotorafi & 5.588 & $6.466,80$ & $7.399,80$ & $181.570,30$ \\
\hline 10. & Permainan interaktif & $3.442,60$ & $3.889,10$ & $4.247,50$ & $4.817,30$ \\
\hline & Penerbitan \& percetakan & 40.227 & $43.757,00$ & $47.896,70$ & $52.037,60$ \\
\hline 12. & Layanan komputer \& Piranti lunak & $6.922,70$ & $8.068,70$ & $9.384,20$ & $10.064,80$ \\
\hline 13. & Radio dan televisi & $13.288,50$ & $15.664,90$ & $17.518,60$ & $20.340,50$ \\
\hline 14. & Riset dan pengembangan & $9.109,10$ & $9.958,00$ & $11.040,90$ & $11.778,50$ \\
\hline \multirow[t]{2}{*}{15.} & Kuliner & $155.044,80$ & $169.707,80$ & $186.768,30$ & $208.632,80$ \\
\hline & Total & 472.999 & 526.999 & $578.760,60$ & $641.815,50$ \\
\hline
\end{tabular}

Sumber: Badan Pusat Statistik (BPS) 
penting seni kriya dalam masyarakat tempo dulu hingga sekarang dapat ditelusuri dari karyakarya yang ada, karya seni kriya dapat dikatakan paling pokok sebagai sarana pendukung bagi masyarakat sosial dalam kehidupan.

Kriya sebagai salah satu sub-sektor dalam Ekonomi Kreatif karena memiliki potensi besar dan sekaligus menjadi ciri khas bangsa Indonesia. Produk seni kriya di Nusantara terkenal dengan hasil dari buatan tangannya dan hal tersebut menjadi nilai tambah. Produk dari seni kriya yang ada di Nusantara meliputi segala kerajinan yang berbahan kayu, keramik, kulit, logam, kaca, dan tekstil.

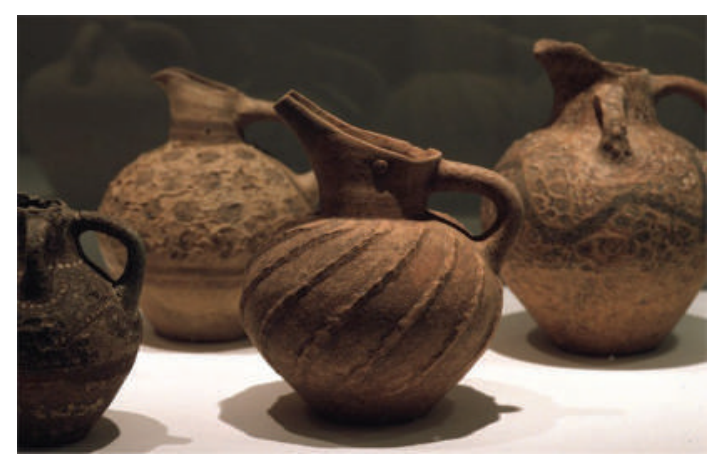

Gambar 1. Produk Seni Kriya Sumber: caraqoo.blogspot.com

\section{Seni Rupa (Pasar Barang Seni)}

Seni rupa merupakan bahasa ungkap seniman lewat karya rupa, sedangkan peran kritikus membedah dan menyampaikan kepada masyarakat, sehingga maksud yang disampaikan oleh seniman sampai dengan tepat kepada masyarakat. Juga dikatakan bahwa seni merupakan olahan atau kristalisasi dari hayalan seniman di dalam penyampaian sikap kritis (Sunarya, 2005:84). Seni murni atau fine art adalah seni yang lahir karena dorongan murni estetik, yaitu keinginan akan pengomunikasian atau pengekspresian hal-hal yang indah yang dirasakan atau dialami seseorang tanpa adanya maksud-maksud lain diluarnya (Soedarso, 2006:101). Elemen- elemen formal suatu karya seni rupa lukis meliputi titik, garis, shape, cahaya, tekstur, massa, ruang dan isi. Bagaimana elemen-elemen ini diorganisir seiring dikatakan sebagai prinsip-prinsip desain atau prinsip mengorganisir elemen-elemen visual.

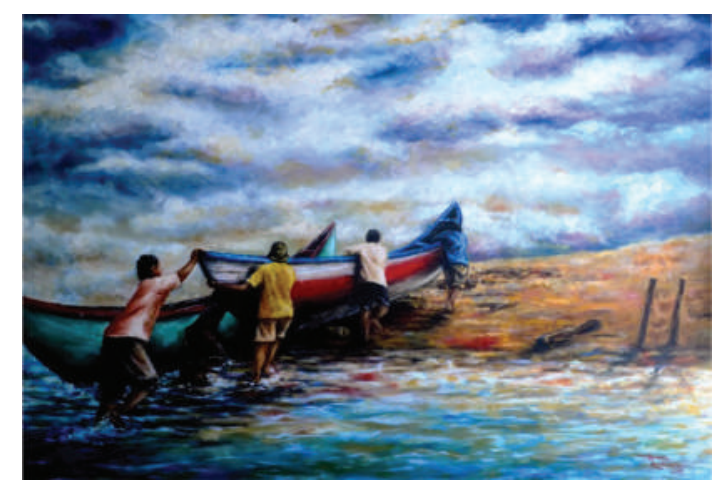

Gambar 2. Lukisan Pulang (2012)

Sumber: suhermankasumba.blogspot.co.id

\section{Tari (Pertunjukan)}

Menurut (Kuswarsantyo, 2012:17) tari adalah salah satu cabang seni yang dalam ungkapannya menggunakan bahasa gerak tubuh. Untuk mencapai kualitas kepenarian yang bagus, seorang penari dituntut penguasaan aspek wiraga, wirama dan wirasa. Namun ternyata tidak hanya cukup penguasaan tiga aspek tersebut agar pemahaman tari secara utuh dipahami. Aspek di luar teknis sebenarnya lebih banyak manfaat yang bisa kita peroleh jika kita mempelajari tari secara kontekstual. Tari dalam perwujudannya senantiasa harus dihayati sebagai bentuk kemanunggalan dari suatu pola imajinatif gerak, ruang, dan waktu yang dapat dilihat dengan kasat mata. Bentuk kemanunggalan antara pola imajinatif dengan pola kasat mata itu dapat dikatakan bahwa tari merupakan suatu bentuk pernyataan ekspresi (jiwani), bentuk pernyataan ilusi, dan sekaligus merupakan bentuk pernyataan rasional manusia. Gerak, ruang, dan waktu dihadirkan sebagai sebuah satu kesatuan yang utuh yang mewakilinya (Supriyanto, 2012:4).

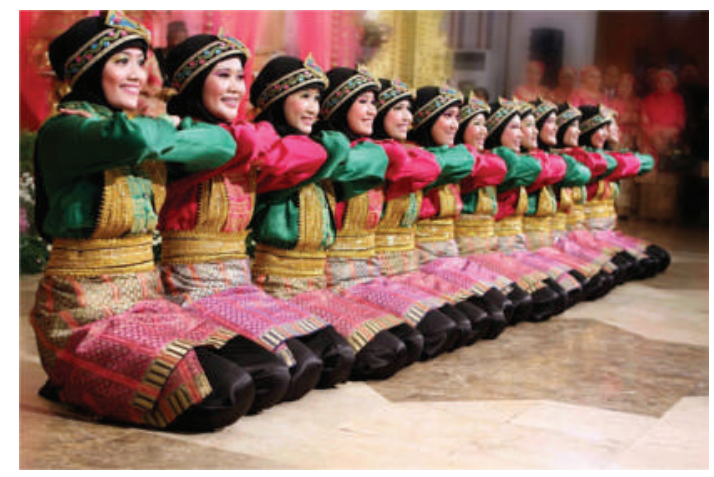

Gambar 3. Tari Saman Aceh Sumber: hipwee.com 


\section{Musik Tradisional (Musik)}

Musik tradisional adalah musik yang digunakan sebagai perwujudan dan nilai budaya yang sesuai dengan tradisi. Dari penjelasan mengenai musik tradisional dapat disimpulkan bahwasanya sebuah ekspresi dan perasaan yang di perankan pada setiap individu melalui nada, suara alat musik irama yang dimainkan berdasarkan tradisi dari suatu kelompok yang diwariskan secara turun temurun (Sedyawati, 1992:23).

Seperti salah satu contoh musik tradisional yang ada di Indonesia, Musik gamelan yang sangat memiliki hubungan erat dengan kultur kehidupan orang kejawen (Jawa) menandakan simbol menjunjung tinggi prinsip hidup dengan mengutamakan musyawarah dan gotong royong. Ketika memainkan musik gamelan, masingmasing penabuh memainkan instrumen namun dikendalikan oleh irama kendang dan ditutup dengan pukulan gong (Prier, 1999:21). Pendapat lain mengatakan musik gamelan dan nyayian liturgi bahasa Jawa menjadi salah satu simbol kesenian yang sangat elok, karena nilai-nilai luhur, iman dan ketaqwaan umat terkandung didalam pembawaanya. Kesenian diaplikasikan sebagai sarana pemujaan kepada tuhan karena mengandung makna tersendiri didalamnya, makna dan nilai-nilai moral yang mendukung penghayatan kepercayaan yang dianut (Hadi, 2006:265).

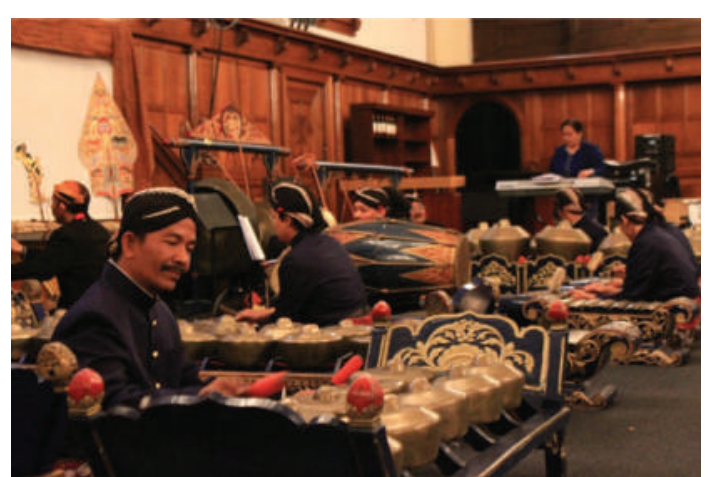

Gambar 4. Gamelan Jawa Sumber: farabicustic2.wordpress.com

\section{Analisis Marketing Mix pada Produk Seni dalam konsep Ekonomi Kreatif}

Teori dari Philip Kotler terkait alat-alat bauran pemasaran (marketing mix) meliputi produk, harga, promosi, dan saluran distribusi/ tempat yang akan peneliti gunakan untuk menganalisis potensi seni guna meningkatkan pertumbuhan ekonomi kreatif yang ada di Indonesia.

\section{a. Analisis Produk (Product)}

Produk Seni Kriya pada proses pembuatannya memusatkan pada keterampilan tangan untuk mengolah bahan baku menjadi produk yang mempunyai nilai guna serta nilai estestis. Terdapat dua jenis dari hasil kriya yaitu produk dua dimensi dan tiga dimensi. Hasil dari produk-produk kriya berupa barang kerajinan yang terbuat dari kayu, bambu, rotan, logam, batu berharga, kulit, dan tanah liat. Produk seni kriya seharusnya bersinergi dengan prinsipprinsip dalam ekonomi jika ingin mendongkrak laju penjualan, yaitu mengedepankan kualitas produk. Kemasan (packaging) dibuat semenarik mungkin disesuaikan dengan sasaran pasar yang dituju. Merek seyogyanya mencerminkan identitas bangsa agar mudah diingat dan diterima. Bentuk ukuran dan warna yang sempurna dapat menarik perhatian khalayak. Dengan pandangan ekonomi kreatif dalam membuat karya kriya secara emplisit akan menghasilkan produk yang terbaik.

Produk Seni Rupa, dalam pembuatanya mencoba merealisasikan konsep seni dengan cara mengekpresikan dalam betuk karya seni. Dalam penjelasan ini akan membahas produk karya seni rupa murni seperti contoh, karya seni rupa dua dimensi dapat kita temukan pada beberapa produk atau benda, di antaranya lukisan, karikatur, kaligrafi dan mozaik. Nilai guna dan nilai akan suatu hal yang indah dan unik didalam produk seni rupa murni tentu akan mendatangkan rasa suka, senang, dan bahkan rasa haru. Hasil dari kreasivitas individu ini tentu akan mendatangkan peluang yang positif selaras dengan konsep ekonomi kreatif yang mana dapat mendatangkan manfaat dan keuntungan bagi penciptanya. Produk ini dikategorikan sebagai (specialty product). Produk konsumen dengan karakteristik unik atau diidentifikasi merek yang dicari oleh kelompok besar pembeli, sehingga pembeli bersedia melakukan usaha khusus untuk membeli. Jika ingin mendapat keuntungan 
yang maksimal dalam penerapan ekonomi kreatif tentu pencipta produk harus membuat keputusan-keputusan yang lebih mengdepankan kualitas/mutu jika kita kaitkan dengan produk seni rupa maka daya tahan produk perlu dipertimbangkan dan juga kemudahan dalam pemeliharaannya.

Produk/jasa Tari Tradisional, di Indonesia tari tradisional menandakan akan keragaman budaya nusantara, hampir di setiap daerah mempunyai tarian khas yang menandakan ciri khas masing-masing, umumnya tarian tradisional menyimpan banyak makna yang terkandung didalamnya dari nilai-nilai filosofis seperti keagamaan, kepahlawanan dsb. Ada dua jenis tari tradisional di indonesia yaitu, tari rakyat dan tari klasik (keraton). Tari Rakyat/tarian daerah merupakan tarian yang berkembang didalam masyarakat biasa menandakan sebagai lambang dari kebahagiaan dan suka cita dewasa ini tarian rakyat terus berkembang dan menjadi tradisi. Tari Klasik (Tari Keraton) tercipta dari dalam keraton atau dalam kaum bangsawan maka masyarakat biasa dilarang untuk menarikan tarian ini. Jika kita kontekskan dengan turis mancanegara yang berkunjung untuk menikmati pesona Indonesia tentu tari tradisional yang beraneka ragam yang ada di daerah-daerah akan mampu menyedot perhatian para wisatawan untuk berdatangan guna sebagai penelitian sejarah maupun sebagai ajang hiburan. Hal ini akan membawa dampak positif bagi kepariwisataan di Indonesia yang akan menambah income bagi negara sehingga ekonomi kreatif yang dihasilkan dari seni tari tradisional membawa angin segar untuk perekonomian Indonesia. Jika kita kategorikan produk tarian tradisional merupakan jenis produk khusus (specialty product). Produk yang memiliki kemasan yang unik atau teridentifikasi produk yang mempunyai ciri khas khusus sehingga tidak kebayakan orang bisa menciptakanya. Mutu produk tarian tradisional Indonesia mengandung banyak makna dan manfaat bagi kehidupan yang salah satunya mengajarkan filosofi keagamaan yang ada di Nusantara dan tentu saja harus dibarengi dengan peningkatan kualitas dalam setiap tarian contoh saja gerakan-gerakan yang lues dan tidak kaku. Kemasan, perbaikan dalam kemasan tari tradisional harus diperhatikan antara lain dari segi pakaian dan peralatan-peralatan yang dipakai penari harus lebih menarik, elegan dan mempunyai warna yang indah sehingga menarik perhatian para konsumen untuk melihatnya. Hal ini perlu diperhatikan bagi para seniman dibidang seni tari tradisional juga harus mengidentifikasi pangsa pasar yang memiliki potensi yang besar dan penseniman tari harus mampu memberikan inovasi-inovasi dalam setiap tarian tradisional.

Produk/jasa Seni Musik Tradisional Nusantara, makna dari seni musik merupakan sebuah ekspresi keindahan yang di luapkan dalam bentuk musik sehingga dapat dirasakan oleh indera pendengaran. Dalam konteks ini akan membahas sebagian produk musik tradisional yang ada di Indonesia yang mempunyai potensi besar untuk mendongkrak perkembangan ekonomi kreatif, hal ini dikarenakan musik tradisional sangat erat kaitanya dengan kehidupan di dalam masyarakat Indonesia karena warisan leluhur secara turun menurun, contoh saja musik Krumpyung adalah sebutan untuk sebuah instrumen yang terdiri dari serangkaian alat musik bambu yang biasa disebut dengan nama Angklung. Nama krumpyung berasal dari bunyi instrumen itu sendiri apabila instrumen tersebut di gerakan. Kesenian ini berasal dari Kelurahan Agrowillis, Wilayah Kecamatan Kokap, Kabupaten Kulon Progo, Yogyakarta. Musik yang dihasilkan oleh bunyi suara angklung yang sangat merdu dan enak di dengar memang sudah menjadi ciri khas bangsa indonesia. Sehingga dalam kehidupan sehari-hari banyak turis mancanegara juga ingin belajar dalam memainkan musik tersebut. Hal ini tentu juga harus diperhatikan oleh para seniman pemusik untuk meningkatkan kualitas yang dihasilkan dalam memainkan musik. Dalam pengemasan produk musik sendiri kurang diperhatikan sehingga penampilan dengan ala kadarnya, hal ini tentu perlu ada perbaikan yang membuat kesan yang elegan, sehingga akan menambah para wisatawan mancanegara untuk berkunjung ke Indonesia. 


\section{b. Analisis Harga (Price)}

Salah satu strategi yang sangat krusial didalam strategi pemasaran yaitu masalah harga. Tetapi dapat diketahui bahwa produk-produk dalam kategori seni memang tidak pernah ada bandrol penetapan harga yang pasti, biasanya penetapan harga dalam produk seni melihat dari tingkat kesulitannya dan bahkan tergantung pada pembelinya artinya jika pembeli/konsumen menyukai akan keindahan produk maka akan berani membeli dengan harga yang relatif tinggi, bahkan terdapat pula sistem penetapan harga dengan cara lelang yang membuat produk terkesan bernilai tinggi dan sangat berharga, dimana pembeli yang berani membayar dengan harga tinggi maka dia yang akan mendapatkan produk tersebut.

Harga dari produk kesenian kriya seperti kerajinan kulit, mebel dan anyaman rotan terkesan masih sangat mahal karena biasanya para konsumenya dari kalangan orang yang memiliki ekonomi yang mapan. Kebanyakan dari Produk kriya juga sudah menyumbangkan angka ekspor di Indonesia hal ini tentu menjadi simbol kesenian dari negara.

Harga dari produk seni rupa juga masih sangat tinggi seperti karya lukis, kerajinan patung dan kerajinan kaca karena memang tingkat kesulitan dalam pembuatan yang tidak kebanyakan orang bisa membuat dan nilai yang tertuang didalam karyanya.

Harga dari produk/jasa tarian-tarian tradisional di Indonesia jika dikaitkan dengan konsep ekonomi tentu harus membandrol dengan harga yang mahal karena tari Nusantara sudah sangat terkemuka diseluruh penjuru dunia, hal ini selarang dengan realita yang terjadi dewasa ini banyak penari-penari yang didatangkan langsung untuk menari dinegaranegara tetangga. tetapi terlepas dari hal itu ada pula tarian-tarian yang senaja tercipta hanya untuk sebagai simbol penghormatan yang didaerah-daerah Nusantara.

Harga dari produk/jasa musik tradisional juga relatif sangat tinggi hal ini karena kekhasan dan kualitas yang dimainkan sangat bagus, seperti halnya musik krumpyung/intrumen musik angklung, musik tradisional seperti ini dewasa ini banyak dicari dan digemari bagi pendengarnya, bahkan penampilanya sangat dinanti-nantikan di sebagian negara tetangga.

Penentuan harga produk-produk seni yang dihasilkan oleh para pencinta seni kreatif memang tidak pernah mencantumkan harga dari produk-produknya seperti halnya produk kebutuhan pokok makanan-makanan dan keperluan rumah tangga. Karena harga dari produk seni sangat tergantung kepada si pembuat dan konsumen, semakin konsumen terkesan kepada barang/jasa yang dikehendaki maka biasanya akan mau membayar dengan harga yang tinggi. Atribut harga produk/jasa pada kreativitas seni yang ditawarkan sudah baik dan harus dipertahankan oleh para penseniman seni. Tetapi lebih eloknya lagi ada sebagaian produk/jasa yang dihasilkan penseniman terdapat daftar harga pasti karena ketika para pelanggan ingin membeli produk atau jasanya sudah mengetahuinya dan di dalam memberikan bandrol harga harus mengetahui pangsa pasar yang dituju apakan kalangan atas atau bawah sehingga semua dapat menkonsumsi produkproduk seni Nusantara, hal ini belom banyak dilakukan. Ada juga penetapan yang harus dibuat yaitu dengan memberikan potongan-potongan harga dan diskon pada sebagaian produk seni karena akan sangat mempengaruhi masyarakat khususnya Indonesia dan Negara lain.

\section{c. Analisis Promosi (Promotion)}

Berarti aktivitas penyaimpain produk seni dalam konsep ekonomi kreatif dengan cara memberitahukan manfaat produk/jasa dan membujuk pasar untuk membelinya. Promosi dibedakan menjadi tiga, yaitu penjualan pribadi (personal selling), penjualan massa (massa selling), dan promosi penjualan (sales promotion). Pertama penjualan produk/ jasa seni dilakuakn menggunakan cara tatap muka (personal selling) hal ini tentu akan efektif karena langsung menjual kepada pelanggan, disini harus ada upaya dari penseniman menunjukkan kelebihan dan kelemahan produk kesenian. Hal seperti itu akan menimbulkan kepuasan pelanggan dan hubungan jangka panjang. Hungan antara penseniman dan pelanggan 
akan menjadikan keunggulan persaingan dengan produk-produk seni Negara lain. kedua, hubungan masyarakat (massa selling) bisa dilakukan dengan cara membuat iklan-iklan melalui media telivisi dan media massa karena hal ini perlu dilakukan untuk mengenalkan kesenian Nusantara yang menjadi simbol kekayaan budaya. Sehingga produk-produk/jasa kesenian akan lebih dipertimbangkan. Ketiga, banyak di jumpai di sekitar kita penjualan produk perusahaan dengan cara iming-iming tulisan diskon $30 \%$ sampai $50 \%$ di sebuah toko atau pusat perbelanjaan. Itulah merupakan salah satu bentuk sales promotion yang bertujuan untuk memancing orang agar segera membeli produk. Tentu hal ini jika dilakukan pada sebagaian produk seni kreatif akan berdampak positif. Contoh saja, misalnya membagikan karya-karya seni kreatifitas seperti souvenir yang terbuat dari anyaman rotan pada eventevent pemasaran produk kesenian Nusantara.

\section{d. Tempat (Place) atau Saluran Distribusi}

Merupakan aktivitas usaha yang membuat produk tersedia bagi pembelinya. Pengaruh dari tempat (Saluran Distribusi) terhadap pilihan pelanggan untuk membeli tentu sangat signifikan, dimana ketersediaan yang mudah didapkat akan berdampak positif untuk penjualan produk/jasa seni. penjual produk/jasa seni jika ingin mencapai maksimal dalam penjualan seharusnya memposisikan produknya secara luas di pasar sehingga dapat lebih dikenali. Penseniman harus memikirkan jarak, lokasi dan banyaknya pasar seni yang mudah dijangkau oleh pelanggan. Sehingga menjadikan produk seni nusantara menjadi pilihan mereka, terlebih dengan tersedianya secara lengkap produkproduk kesenian yang mereka inginkan dan butuhkan.

\section{KESIMPULAN}

Perkembangan ekonomi kreatif di Indonesia dari tahun ke tahun mengalami peningkatan yang semakin menjajikan bagi pertumbuhan ekonomi Negara, karena banyaknya SDM yang semakin kreatif. Tentu hal ini harus mendapat dukungan yang maksimal dari pemerintah.

\section{DAFTAR PUSTAKA}

Anggraini, N. 2008. Industri Kreatif. "Jurnal Ekonomi ," 8(3), 144-151.

Gilarso. 2004. Pengantar ilmu ekonomi makro, edisi revisi. Yogyakarta: kanisius.

Hadi, Y. S. 2006. Seni Dalam Ritual Agama. Yogyakarta: Buku Pustaka.

Hasoloan, J. 2010. Pengantar Ilmu Ekonomi (PIE). Yogyakarta: Deepublish.

Humardani, S. 1980. Dasar-dasar Estetika (terjemahan). Surakarta: Akademi Seni Karawitan Indonesia.

Inpres. 2009. Instruksi Presiden Republik Indonesia, Nomor 6, Tentang Pengembangan Ekonomi Kreatif.

Kotler, P. 2000. Manajemen Pemasaran, Jilid 2. Jakarta: Bumi Aksara.

Kusmadi. 2010. Seni Kriya Dalam Kehidupan Manusia. Jurnal Ornamen, 7(1), 63-70.

Kuswarsantyo. 2012. Pelajaran Tari: Image Dan Kontribusinya Terhadap Pembentukan Karakter Anak. Jurnal Joged Seni Tari, 3(1), 17-23.

Margono, D. 2007. Apresiasi Seni Rupa dan Seni Teater 2. Perpustakaan nasional: KDT.

Parker, D. W. H. 1946. The Principles of Aestethics. New York: Appleton Century Crafts.

Perpres. 2015. Peraturan Presiden Republik Indonesia Nomor 72 Tahun 2015 Tentang Perubahan Atas Peraturan Presiden Nomor 6 Tahun 2015 Tentang Badan Ekonomi Kreatif. www.Hukum Online, 1-5.

Prier, K.-E. 1999. Inkulturasi Musik Liturgi. Yogyakarta: Pusat Musik Liturgi.

Putra, P. A., \& Soehartono, F. 2012. Pusat Pagelaraan Pelatihan dan Galeri Seni Tari Tradisional Di Bali. eDimensi Arsitektur, (1), 1-5.

Read, Herbert. 1959. The Meaning Of Art. New York: Pinguin Book.

Romarina, A. 2016. Economic Resilience Pada Industri Kreatif Guna Menghadapi Globalisasi Dalam Rangka Ketahanan Nasional. Jurnal Ilmu Sosial, 15(1), 3552. 
Saksono, H. 2012. Creative Economy: New Talents For Regional Competitiveness Triggers. Jurnal Bina Praja, 4(2), 93-104. Sedyawati, Edy. 1992. Budaya Indonesia: Kajian Arkeologi, Seni dan Sejarah. Jakarta: Rajawali Pers - Citra Niaga.

Soedarso SP. 2006. Trilogi Seni Penciptaan, Eksistensi, dan Kegunaan Seni. Yogyakarta: BP ISI Yogyakarta.

Sukoco, I., \& Fadillah, A. R. 2016. The Analysis Of Talent Management Strategy Using Organizational Competency Approach In Pt Pindad (Persero) Bandung City. Jurnal AdBispreneur, 1(1), 85-102.

Sunarya, I. K. 2005. Seni kriya Sebuah Kajian

Teks dan Konteks. Jurnal Ornamen Seni Rupa STSI, 2(1), 80-100.

Supriyanto. 2012. Tari Klana Alus Sri Suwela Gaya Yogyakarta Perspektif Joged Mataram. Jurnal Joged Seni Tari, 3(1), 1-15.

Sutardi, T. 2007. Antropologi Mengungkap Keragaman Budaya. Bandung: Pt Setia Purna Inves.
Tridayanti, G. 2014. Fungsi Tari Rembara Sebagai Media Komunikasi Budaya Pada Masyarakat di Kabupaten Paser. eJurnal Ilmu Komunikasi, 2(3), 396-405.

UUD, 1945. 2010. Undang Undang Dasar 1945 Amandemen Pertama s/d Keempat. Jakarta: jogja bangkit.

Wijaya, P. 2001. Mengenal lebih dekat: Putu Wijaya Sang Teroris Mental dan Pertanggung Jawaban Proses Kretifitasnya. Jakarta: Yayasan Obor Indonesia.

\section{Webtografi:}

https://caraqoo.blogspot.com

https://suhermankasumba.blogspot.co.id https://hipwee.com

https://farabicustic2.wordpress.com 